\author{
Malgorzata Zdon-Korzeniowska \\ Uniwersytet Pedagogiczny \\ im. Komisji Edukacji Narodowej \\ w Krakowie
}

\title{
Marketing terytorialny jako forma działań przedsiębiorczych samorządów terytorialnych w Polsce
}

Procesy globalizacyjne - ich zasięg, przebieg i struktura - są trudne do zdefiniowania, a skutki niełatwe do przewidzenia. Jest to obecnie najszerszy, najbardziej złożony, fundamentalny proces zmian zachodzących w sferze gospodarczej i społecznej (Gregor 2006). Trudno jednoznacznie zdefiniować owo coś, co określamy mianem globalizacji. Wielowymiarowość i zasięg tego wieloaspektowego i trwającego wciąż zjawiska są trudne do ogarnięcia i sprecyzowania. Wydaje się, że najbardziej lakoniczne i ogólne jego określenie jako 'tworzenie globalnej wioski, globalnego świata' paradoksalnie najpełniej ujmuje jego istotę i zakres. Sukcesywna likwidacja barier handlowych i inwestycyjnych, rozwój środków transportu i komunikacji, a także szybki przepływ informacji w mediach powodują niespotykane do tej pory zmiany w sferze społecznej, gospodarczej, kulturowej i politycznej. Wszystko to znacząco przeobraża warunki funkcjonowania nie tylko poszczególnych osób i podmiotów gospodarczych, ale i całych społeczeństw, gospodarek narodowych czy też szerszych ich ugrupowań. Zaistniałe warunki wpływają z kolei na zachowania wymienionych podmiotów, które jak woda na młyńskie koło napędzają spiralę globalizacji. Tworzy się tzw. globalny rynek, zacierają różnice kulturowe, unifikuje styl życia charakteryzujący globalnego konsumenta, który nabywa dobra i usługi oferowane przez transnarodowe korporacje.

Tendencja do zwiększania swobody i szybkości przepływu kapitału, osób, a także dóbr i usług otwiera przed podmiotami gospodarczymi i obywatelami szczególne możliwości. Są one związane m.in. ze swobodą wyboru miejsca prowadzenia działalności gospodarczej, miejsca zamieszkania, miejsca podjęcia pracy czy też miejsca wypoczynku. Powyższe stwarza szczególne perspektywy, ale i poważne wyzwania dla miejsc recepcji inwestycji, przedsiębiorstw czy osób, a więc dla jednostek terytorialnych. Chcąc sprostać wymogom globalnego rynku, muszą one wykazać się elastycznością, innowacyjnością i rynkowym podejściem, przystosowując się do potrzeb zainteresowanych grup klientów: przedsiębiorców, turystów, mieszkańców, inwestorów. W warunkach globalizacji bowiem, jak zauważa T. Markowski, presja konkurencyjna wzrasta „nie tylko na producentów dóbr rynkowych, ale także na jakość otoczeń przestrzenno-gospodarczych, w których działają producenci” (Markowski 2006, s. 89). Tworzy się więc swoisty rynek, na którym określone jednostki administracyjne konkurują ze sobą o kapitał i klientów. Aby wygrać tę grę konkurencyjną, muszą wykazać się przedsiębiorczością i znajomością reguł rynkowych. Muszą dostrzec pojawiające się szanse i możliwości rozwoju oraz mieć odwagę, ale i wystarczającą wiedzę, aby móc z nich skorzystać. Zdaniem B. Gregora (2006), globalny rynek w ogóle powinien być traktowany jako szansa, a nie bariera rozwoju. A konkurencja na globalnym rynku - jak wskazuje autor - opierać się będzie przede wszystkim na wiedzy, innowacjach i nowoczesnym marketingu (Gregor 2006). 
Współczesną tendencją, stanowiącą niejako przeciwwagę dla tego, co niosą procesy globalizacyjne, jest „eksponowanie tego, co specyficzne i lokalne oraz zintegrowane wokół wspólnego celu" (Bieńkowska 2004, s. 184). Obserwuje się silną tendencję do podkreślania własnej przynależności regionalnej, do identyfikowania się z tzw. małymi ojczyznami. Pojawia się swego rodzaju paradoks tzw. glokalności, wyrażający jednoczesność globalności i lokalności działań samorządów terytorialnych (Barczyk 2010).

W Polsce - zgodnie z przyjętą ideą decentralizacji władzy publicznej - samorząd terytorialny jest podmiotem zarządzającym sprawami lokalnymi i regionalnymi (Majewska 2006), a więc tym, który odpowiada za gospodarowanie specyficznymi, unikatowymi zasobami określonych obszarów. Po reformie administracyjnej z 1999 r. samorządy uzyskały nowe, szersze kompetencje i większą swobodę działania, co umożliwiło im realizację roli menedżerów jednostek terytorialnych, którymi zarządzają, i stało się szansą na przejęcie swoich spraw we własne ręce, a tym samym posiadanie wpływu na kierunki rozwoju małych ojczyzn. Z drugiej jednak strony rozszerzyło to spektrum wyzwań, które stanęły przed samorządami - spektrum kryjące w sobie niespotykane do tej pory szanse i możliwości, ale i zagrożenia. Aby wykorzystać pojawiające się szanse i możliwości, jednocześnie skutecznie unikając zagrożeń, samorządy terytorialne muszą - jak już wyżej wspomniano - wykazać się przedsiębiorczością i innowacyjnym podejściem.

Zdaniem A. Szromnika (2007), zarządzanie jednostkami terytorialnymi powinno opierać się na dorobku nauk o zarządzaniu przedsiębiorstwami, a myślenie przedsiębiorcze powinno być podstawą podejmowania decyzji w instytucjach samorządowych. Według tego autora, jest to podstawowy warunek ich rozwoju. „Dowolne miasto lub region, ale także wieś, dzielnica czy osiedle, są nie tylko organizmami społecznymi i jednostkami samorządności terytorialnej. Ale także pełnoprawnymi uczestnikami rynku, którzy prowadzą różnorodną działalność, posiadają okresowe zasoby i wykorzystują je dla dobra mieszkańców. Dopuszczalne są analogie między jednostkami przestrzenno-administracyjnymi a przedsiębiorstwami, między samorządową kadrą zarządzającą a kadrą menedżerską, między wójtami, starostami, burmistrzami i prezydentami miasta a dyrektorami i prezesami firm" (Szromnik 2007, s. 11).

Wykorzystanie koncepcji marketingowej bez wątpienia uznać można za jedną z form realizacji działań przedsiębiorczych samorządów terytorialnych w warunkach globalizacji. W niniejszym opracowaniu zawarto rozważania na temat zastosowania marketingu terytorialnego przez jednostki administracji publicznej do zarządzania własnym rozwojem. Opracowanie to nie jest jednak prezentacją wyników badań nad wyżej określoną problematyką. Ma ono raczej charakter rozważań wstępnych, jest swego rodzaju preludium do badań, które autorka zamierza podjąć. Przesłanką do sformułowania niniejszej problematyki badawczej były przeprowadzone wcześniej przez autorkę badania i analizy w zakresie kształtowania regionalnych produktów turystycznych w Polsce (zob. M. Zdon-Korzeniowska, Jak kształtować regionalne produkty turystyczne? Teoria i praktyka, Wyd. UJ, Kraków 2009). Badania te dotyczyły m.in. aktywności samorządów szczebla wojewódzkiego w zakresie budowy i kształtowania tych produktów. Obecnie autorka zamierza rozszerzyć zakres i przedmiot badań, a przede wszystkim uwzględnić w nich samorządy lokalne - zwłaszcza samorządy gminne, które mają największe rzeczywiste możliwości działań związanych z m.in. kształtowaniem oferty terytorialnej oraz inne poza turystyczną - rodzaje ofert, a więc tzw. złożony terytorialny megaprodukt stanowiący sumę subproduktów terytorialnych (takich jak subprodukt inwestycyjny, kulturalno-oświatowy, konferencyjny, handlowo-usługowy itp.).

Koncepcja marketingu terytorialnego wywodzi się z nowszych orientacji marketingowych z tzw. koncepcji marketingu społecznego, zgodnie z którą, według Ph. Kotlera, ,zadanie organizacji polega na określeniu potrzeb, wymagań i interesów rynków docelowych oraz dostarczeniu pożądanego zadowolenia w sposób bardziej efektywny i wydajny niż konkurenci, przy 
jednoczesnym zachowaniu lub podniesieniu dobrobytu konsumenta i społeczeństwa" (Kotler 1994, s. 26). Tak definiowana koncepcja marketingowa ma na uwadze nie tylko zysk przedsiębiorstwa, ale - stawiając w centrum zainteresowania potrzeby pojedynczego konsumenta zmierza w kierunku zaspakajania potrzeb znacznie szerszej społeczności (miejskiej, lokalnej, regionalnej), potrzeb w dziedzinie jakości życia, rozwoju społecznie odpowiedzialnego (Gołembski 1999).

Marketingowa koncepcja funkcjonowania jednostek terytorialnych (gmin, miast, powiatów, regionów i innych obszarów) polega na traktowaniu podmiotów znajdujących się na ich terenie (na tzw. rynku wewnętrznym) oraz na terenie innych jednostek terytorialnych (tzw. rynku zewnętrznym) jako specyficznego rodzaju klientów, o których należy zabiegać. W przypadku niezaspokojenia ich potrzeb i pragnień mogą oni np.: zmienić swoje miejsce zamieszkania czy prowadzenia działalności gospodarczej lub nie zdecydować się na podjęcie tej działalności na terenie danej jednostki albo też nie wybrać jej jako miejsca wypoczynku. W podejściu marketingowym bowiem punktem odniesienia wszelkich działań jest klient i jego potrzeby. Kluczowe staje się zatem zdefiniowanie grup klientów (tzw. rynków docelowych) i rozpoznanie ich potrzeb na podstawie badań marketingowych.

Marketing terytorialny - jak twierdzi T. Markowski - powstał w wyniku próby przeniesienia i adaptacji koncepcji sprzedaży i zarządzania wypracowanych dla typowych produktów w sektorze prywatnym do sektora publicznego (Markowski 1999). Według tego autora, jest to wyjście na przeciw potrzebie profesjonalizacji zarządzania jednostkami terytorialnymi i ich rozwojem, potrzebie, która pojawiała się w konsekwencji odpowiedzi na wyzwania globalizacji gospodarki światowej oraz wzrastającej presji konkurencyjnej nie tylko na producentów dóbr rynkowych, ale także presji konkurencyjnej na jakość otoczeń przestrzenno-gospodarczych, w których działają producenci (Markowski 1999).

A. Szromnik definiuje marketing terytorialny jako całokształt skoordynowanych działań podmiotów lokalnych, regionalnych i/lub ogólnokrajowych zmierzających do wykreowania procesów wymiany i oddziaływania poprzez rozpoznanie, kształtowanie i zaspokajanie potrzeb oraz pragnień mieszkańców (Szromnik 1997). Mieszkańcy są podstawową grupą docelową w działaniach marketingowych samorządów terytorialnych. Można rzec, że są to klienci „,niezbywalni”, a dążenie do zaspokojenia ich potrzeb i pragnień generuje niejako pozostałe grupy adresatów oferty terytorialnej (inwestorów, turystów, pracowników instytucji publicznych, banki oraz inne instytucje czy organizacje).

Marketing terytorialny, gdzie podstawą procesów wymiany, punktem odniesienia działań marketingowych jest dane miejsce (Szromnik 2006) (terytorium) określany jest również jako marketing miejsc od angielskiego określenia place marketing (Kotler, Haider, Rein 1993), który zakłada planowanie i projektowanie danego miejsca w tak sposób, żeby w pełni zaspokoić potrzeby rynków docelowych, tj. mieszkańców, podmiotów gospodarczych, a także odwiedzających i inwestorów. Zastosowanie koncepcji marketingowej do promocji i niejako sprzedaży miejsc zmusza władze lokalne oraz regionalne do spojrzenia na jednostki terytorialne, którymi zarządzają, pod nieco innym kątem.

Obecnie w Polsce jednostki terytorialne wszystkich szczebli w mniejszym lub większym stopniu przyjmują orientację marketingową. Są świadome konieczności działań marketingowych, jednak nie wykorzystują wszystkich dostępnych narzędzi. Jak się wydaje, główną barierą jest nieznajomość pojęć, metod i narzędzi marketingowych. Ciągle dla wielu osób marketing jest mało zrozumiały i utożsamiany tylko i wyłącznie z reklamą czy promocją. Wiedzę i narzędzia z zakresu marketingu, $\mathrm{w}$ tym również marketingu terytorialnego, często stosuje się selektywnie, ograniczając je do promocji czy kształtowania wizerunku, a zapominając o powiązaniu 
ich z innymi instrumentami marketingowego oddziaływania, takimi jak produkt, dystrybucja, cena, środowisko świadczenia usług, personel itp. O sukcesie bowiem marketingowych działań przesądza odpowiedni dobór instrumentów marketingowego oddziaływania, ich spójność i niepreferowanie jednych kosztem innych. Jak wskazują Ph. Kotler i N. Lee, utożsamianie marketingu z jednym tylko jego narzędziem, a więc ograniczanie go do działań związanych z promocją, „oznacza niedostrzegania potęgi myślenia marketingowego i płynących z niego korzyści” (Kotler, Lee 2008, s. 9).

Każda jednostka administracyjna sama powinna kształtować użyteczny dla niej zestaw narzędzi marketingowych, a więc skomponować tzw. mieszankę marketingową (znaną w nomenklaturze marketingowej pod nazwą marketing-mix). W literaturze przedmiotu istnieje wiele propozycji tego typu zestawów, pojawiły się również i takie, które opracowano właśnie z myślą o marketingu jednostek terytorialnych. W tabeli 1 zostały przedstawione wybrane $\mathrm{z}$ nich, użyteczne z punktu widzenia marketingu jednostek terytorialnych.

Tab. 1. Propozycje koncepcji marketingu-mix dla jednostek terytorialnych

\begin{tabular}{|c|c|}
\hline Nazwa koncepcji & Narzędzia marketingowego oddziaływania \\
\hline $\begin{array}{c}\text { Koncepcja „4P”, } \\
\text { E.J. McCarthy’ego }\end{array}$ & $\begin{array}{c}\text { product - produkt } \\
\text { price }- \text { cena } \\
\text { place - miejsce, dystrybucja } \\
\text { promotion - promocja }\end{array}$ \\
\hline Koncepcja „7P” & $\begin{array}{c}\text { "4P" }+ \text { : } \\
\text { people - ludzie (pracownicy i personel) } \\
\text { physical evidence - cechy fizyczne lub środowisko materialne } \\
\text { proces - proces lub procedura świadczenia usług }\end{array}$ \\
\hline $\begin{array}{l}\text { Terytorialny marketing-mix } \\
\text { wg M. Florek }\end{array}$ & $\begin{array}{l}\text { megaprodukt } \\
\text { promocja } \\
\text { partnerstwo } \\
\text { tożsamość }\end{array}$ \\
\hline $\begin{array}{c}\text { Terytorialny marketing-mix } \\
\text { wg Ph. Kotlera, D.H. Haidera } \\
\text { i I. Reina }\end{array}$ & $\begin{array}{l}\text { infrastruktura } \\
\text { ludzie } \\
\text { atrakcje } \\
\text { image i jakość życia }\end{array}$ \\
\hline
\end{tabular}

Źródło: A. Szromnik, Marketing terytorialny - koncepcja ogólna a doświadczenia praktyczne [w:] Marketing terytorialny, red. T. Markowski, TOM CXVI, PAN KPZK, Warszawa 2006, s. 65-72; M. Florek, Podstawy marketingu terytorialnego, Wyd. AE w Poznaniu 2006, Poznań, s. 170-174; Ph. Kotler D.H. Haider, I. Rein, Marketing Places. Attracting Investment, Industry and Tourism to Cities, States and Nations, The Free Press, New York 1993, s. 19.

Współcześnie najpopularniejszą formułą marketingu-mix, również jeśli chodzi o marketing jednostek terytorialnych, jest „4P” (Baruk 2001). Zgodnie z tą koncepcją użytecznymi narzędziami stymulowania zachowań odbiorców (Szromnik 2006) są:

- product (produkt) - odpowiednia kompozycja cech oferowanego produktu,

- $\operatorname{price}$ (cena) - warunki cenowe transakcji,

- place (miejsce, dystrybucja) - odpowiednie miejsce, forma i czas oferowania produktu,

- promotion (promocja) - formy i środki promocji (komunikacji). 
Powyższa koncepcja wyrosła z doświadczeń marketingu komercyjnego. Z tego też względu działania marketingowe zorganizowane według formuły „4P” posiadają pewne ograniczenia, które utrudniają (lub wręcz uniemożliwiają) ich pełne adaptowanie do potrzeb marketingu terytorialnego (Szromnik 2006).

Z punktu widzenia działań marketingowych związanych z kształtowaniem produktów o charakterze przestrzennym szczególnie ważną wydaje się być koncepcja instrumentów marketingowych w formule „7P”. Koncepcja ta, zaprojektowana z uwzględnieniem specyfiki produktów o charakterze usługowym, poszerza tradycyjną koncepcję „4P” o kolejne trzy obszary marketingowej aktywności:

- people-pracownicy i personel,

- physical evidence - cechy fizyczne lub środowisko materialne;

- proces - proces lub procedura świadczenia usług.

Ze względu na fakt, że złożony megaprodukt terytorialny ma w znacznej mierze charakter usługowy, formuła ,7P” marketingu-mix wydaje się być szczególnie przydatna w definiowaniu obszarów aktywności marketingowej związanej z kształtowaniem tego produktu.

W literaturze przedmiotu znaleźć można również zestawy narzędzi opracowane z myślą o marketingu jednostek terytorialnych, choć jak zauważa M. Florek, mieszanka ,instrumentów marketingu terytorialnego jest wciąż przedmiotem poszukiwań” (Florek 2006, s. 170).

Jedną z pierwszych tego typu propozycji jest terytorialny marketing-mix opracowany przez Ph. Kotlera, D.H. Haidera i I. Reina (1993). Według tych autorów, całokształt świadomych i celowych działań marketingowych podejmowanych przez jednostki terytorialne sprowadza się do (Szromnik 2006):

- kształtowania cech infrastruktury - zarówno ilościowych, jak i jakościowych (infrastruktura),

- przygotowania personelu samorządowego oraz mieszkańców do kontaktowania się i obsługi gości przez właściwe procedury rekrutacyjne, szkoleniowe, motywacyjne informacyjne (ludzie),

- organizacji atrakcji w postaci jednorazowych i cyklicznych wydarzeń oraz imprez masowych o charakterze kulturalnym, sportowym, artystycznym, handlowym, turystycznym (atrakcje),

- kształtowania pozytywnego, wyraźnego i trwałego wizerunku (image) jednostki terytorialnej poprzez szeroką oraz zintegrowaną działalność informacyjno-propagandową, angażującą wszystkie podmioty i osoby (image i jakość życia).

Zatem zaproponowane przez wyżej wymienionych autorów instrumentarium marketingowego oddziaływania dla jednostek terytorialnych obejmuje następujące elementy: infrastrukturę, ludzi, atrakcje oraz wizerunek i jakość życia.

Na szczególną uwagę zasługuje propozycja nowatorskiej mieszanki instrumentów marketingu terytorialnego zaproponowana przez M. Florek (2006). Autorka ta wymienia następujące instrumenty: kształtowanie oferty terytorialnej (megaproduktu regionalnego), komunikowanie się regionu z otoczeniem (promocję), działania podmiotów w regionie (partnerstwo) oraz tożsamość, którą uznaje za nadrzędny, w stosunku do pozostałych, instrument marketingowego oddziaływania. Taka konfiguracja obszarów aktywności marketingowej wydaje się być szczególnie użyteczna w aspekcie marketingu prowadzonego przez jednostki terytorialne, integruje bowiem istotne dla tego typu aktywności aspekty. Uwzględnia złożony zdeterminowany przestrzennie produkt terytorialny, kładzie również nacisk na konieczność współdziałania podmiotów jako niezbędnego warunku skuteczności podejmowanych działań marketingowych. Ponadto wskazuje na tożsamość danego miejsca, której właściwe zdefiniowanie i zaprojektowanie wpływa nie tylko na unikatowość i spójność oferty, ale jest również warunkiem kreowania wyraźnego, pożądanego wizerunku danej jednostki terytorialnej. Wyodrębnione przez autorkę 
partnerstwo jako instrument terytorialnego marketingu-mix jest natomiast istotnym czynnikiem wspomagającym efektywność działań podejmowanych w związku z kształtowaniem zintegrowanych, zdeterminowanych przestrzennie produktów.

Zaprezentowane wyżej zestawy marketingu-mix wskazują na potencjalne obszary marketingowej aktywności jednostek terytorialnych. Najpopularniejszym jednak zestawem narzędzi marketingowych stosowanym w zakresie marketingu terytorialnego, mimo wielu głosów krytycznych i aplikacyjnej ograniczoności, jest klasyczna koncepcja „4P”. Aby możliwe było jednak efektywne zastosowanie proponowanego w niej zestawu narzędzi, wymaga ona przede wszystkim redefinicji produktu w kierunku złożonego megaproduktu terytorialnego, a także interpretacji dystrybucji jako dostępności danego miejsca (jednostki terytorialnej) i oferowanych przezeń produktów terytorialnych. Ponadto ważnym jest, aby instrumentarium promocyjne zawierało szczególnie użyteczne narzędzia dla prowadzenie polityki promocji jednostek terytorialnych, a więc działania z zakresu public relations.

Z całego zestawu „4P” najmniej celowe i możliwe do zastosowania przez jednostki terytorialne jest prowadzenie zintegrowanej strategii cenowej (Florek 2006), większe możliwości integrowania działań daje aktywność w sferze dystrybucji (dostępności), a zwłaszcza promocji. Kształtowanie samego megaperoduktu terytorialnego, choć ma duże znaczenie z punktu widzenia marketingu terytorialnego, cechuje ograniczona możliwość integracji i koordynacji działań. Najpowszechniej stosowanym narzędziem działań marketingowych jednostek terytorialnych jest promocja. Strategia promocji ma również największe znaczenie dla marketingu terytorialnego, jest też obszarem aktywności w największym stopniu umożliwiającym integrację i koordynację działań.

Podsumowując ogół rozważań dotyczących doboru instrumentów marketingowego oddziaływania w związku z kształtowaniem rpt, należy stwierdzić, że przeniesienie instrumentów marketingowych na poziom jednostek terytorialnych czy też opracowanie odrębnego zestawu tych instrumentów dla zarządzania jednostkami terytorialnymi jest sprawą niezwykle trudną. Wynika to głównie z ogromnej złożoności „organizmu” czy „organizacji”, jaką jest jednostka terytorialna, różnorodności i złożoności oferowanych przezeń w ramach megaproduktu subproduktów terytorialnych, a także wielości podmiotów współtworzących te zintegrowane, przestrzenne koncepcje produktów. Trudność ta związana jest też z wielowymiarowością procesów zachodzących w ramach zarządzania daną jednostka terytorialną.

M. Florek (2006) wśród czynników wpływających na wybór optymalnego zestawu instrumentów marketingowych dla jednostek terytorialnych wymienia m.in.:

- cechy i strukturę oferowanego megaproduktu terytorialnego,

- cele marketingowe jednostki terytorialnej,

- pozycję konkurencyjną jednostki terytorialnej,

- charakter segmentu docelowego,

- koszt i wysokość nakładów na poszczególne narzędzia.

Każda jednostka terytorialna kształtuje zatem własną kompozycję narzędzi marketingowych. O sukcesie ich zastosowania decyduje spójność i niepreferowanie jednych instrumentów kosztem innych (np.: nienadużywanie działań promocyjnych względem działań związanych z kształtowaniem struktury produktu, jego jakości czy dostępności). Warto także zwrócić uwagę na fakt, że wypracowana kompozycja narzędzi marketingowych nie jest stała w czasie, a jej struktura może ulegać modyfikacjom na skutek zmian warunków wewnętrznych i zewnętrznych oraz stopnia realizacji założonych celów (Florek 2006).

$\mathrm{Z}$ przeprowadzonych $\mathrm{w}$ zakresie kształtowania regionalnych produktów turystycznych, a wspominanych na wstępie badań wynika, że w strukturze działań marketingowych samorządów działania z zakresu promocji oraz kształtowania wizerunku przeważają nad działaniami 
związanymi z tworzeniem pełnej, zintegrowanej oferty (Zdon-Korzeniowska 2009). W niewystarczającym zakresie lub wcale nie uwzględnia się również działań na rzecz zwiększenia dostępności produktu, co m.in. jest warunkiem jego efektywnej komercjalizacji.

Przykład powyższej sytuacji stanowi Szlak Architektury Drewnianej (dalej: Szlak AD), który uznać możemy za subprodukt turystyczny będący częścią megaproduktu województwa małopolskiego. Szlak ten jest przedmiotem analizy w ramach poniższego studium przypadku.

W przypadku działań marketingowych związanych z kształtowaniem produktu turystycznego: Szlak AD, zdecydowanie przeważają działania na rzecz promocji dokonujące się, jak się wydaje, kosztem dostępności tego produktu. Informacje uzyskane podczas wywiadów przeprowadzonych w punkcie informacji turystycznej przy ul. Wiślnej $12 \mathrm{w}$ Krakowie z pracownikami tejże placówki oraz analiza wyników badań ruchu turystycznego przeprowadzonych w 2006 r. w województwie małopolskim pod względem sposobu organizacji i celu przyjazdu do Małopolski (Badanie ruchu turystycznego 2006) wskazują, że znaczna część turystów - zwłaszcza zagranicznych - nie miała możliwości skorzystania z oferty Szlaku AD. Prawdopodobnie stało się tak ze względu jego słabą dostępność: transportową bądź też np. związaną z warunkami udostępniania obiektów. Zdaniem przedstawicieli punktu informacji turystycznej przy ul. Wiślnej 12, Szlak AD cieszy się dużym zainteresowaniem, zwłaszcza wśród turystów zagranicznych. Osoby, które chciałyby przemierzyć ten szlak, docierają na ul. Wiślną 12, gdzie rozpoczyna się i jednocześnie kończy ich wycieczka. Otrzymują tu profesjonalnie przygotowane i opatrzone licznymi fotografiami foldery czy informatory o szlaku i obiektach architektury drewnianej, ale, nie dysponując własnym środkiem transportu, nie mają możliwości skorzystania z oferty. Jak wskazują bowiem wyniki badań ruchu turystycznego, tylko nieco ponad 18\% turystów zagranicznych przyjeżdża do Małopolski samochodami, a ponad połowa (53\%) przylatuje samolotem (Badanie ruchu turystycznego 2006).

Barierą w skorzystaniu z oferty Szlaku AD dla turystów zagranicznych jest zatem prawdopodobnie ograniczona dostępność transportowa - i to zarówno pod względem dysponowania środkiem transportu, jak i pod względem sprawności dojazdu do poszczególnych obiektów. Bowiem jeżeli turysta zagraniczny jest nawet zmotoryzowany, a Szlak AD oznakowany, to zwiedzanie poszczególnych, leżących w różnych zakątkach regionu i oddalonych od siebie o kilkanaście czy kilkadziesiąt kilometrów, zabytków architektury drewnianej może być dla niego, gdy nie zna terenu i języka polskiego, stosunkowo dużym wyzwaniem. Ponadto możliwość zwiedzenia niektórych obiektów jest ograniczona ze względu na warunki udostępniania wnętrz, gdyż nie są one przystosowane do obsługi ruchu turystycznego i nie ma np. wyznaczanych godzin zwiedzania, co w niektórych przypadkach wymaga wykonania wcześniejszego telefonu do proboszcza parafii, w celu uzgodnienia terminu zwiedzania obiektu. Barierą przy zwiedzaniu obiektów ze Szlaku $\mathrm{AD}$ jest dla turystów zagranicznych również nieznajomość języka polskiego.

Należałoby zatem podjąć działania na rzecz zwiększenia dostępności oferty produktu turystycznego Szlak AD poprzez np.:

- wyznaczenie godzin otwarcia i zasad zwiedzania obiektów drewnianych i udostępnienie turystom pełnej informacji w tym zakresie,

- organizację specjalnych, regularnych przejazdów autokarowych wzdłuż szlaku,

- zaktywizowanie biur podróży na rzecz organizacji wycieczek Szlakiem AD lub też nawiązanie regularnej współpracy w tym zakresie,

- uzupełnienie oferty Szlaku AD o usługi przewodnickie skierowane również do turystów zagranicznych,

- nawiązanie współpracy np.: z wypożyczalnią samochodów lub inną firmą transportową w celu oferowania przejazdu, a tym samym możliwości zwiedzenia Szlaku AD zainteresowanym, ale niezmotoryzowanym turystom. 
Powyższe działania, zwłaszcza w wypadku turystów zagranicznych, mogą przyczynić się do wzrostu możliwości skorzystania z oferty produktu turystycznego: Szlak AD. Dostępność produktu bowiem czy też możliwość skorzystania z oferty w momencie rozpoczęcia i prowadzenia działań związanych z promocją produktu, są warunkiem jego efektywnej komercjalizacji. Istotnym jest więc, aby propozycje te zostały włączone do całościowej oferty Szlaku AD, a skorzystanie z nich było możliwe $\mathrm{w}$ określonym, dostępnym dla turystów miejscu i czasie.

Powyższy przykład pokazuje, jak niespójność i wybiórcze stosowanie narzędzi marketingowych prowadzi do mniejszej efektywności.

Poza niepełnym i niespójnym wykorzystaniem instrumentów marketingowego oddziaływania, zakres podejmowanych przez samorządy działań nie obejmuje też stosownych badań marketingowych. Co więcej, wydaje się, że w niewielkim lub znikomym stopniu, przy kształtowaniu oferty, wykorzystuje się dostępne wyniki badań i wtórne dane dotyczące zachowań i potrzeb klientów.

Jakie są zatem przyczyny niepełnego wykorzystania i zastosowania narzędzi i metod z zakresu marketingu terytorialnego przez samorządy? Czy jest to nieznajomość tej koncepcji, niejasność i niepełne jej zrozumienie czy też może - co w pewnym zakresie potwierdzają również przeprowadzone przez autorkę badania - samorządy po prostu nie dostrzegają korzyści płynących z zastosowania metod i narzędzi marketingowego oddziaływania do zarządzania własnym rozwojem? Z czego wynika ta niska świadomość? Udzielenie odpowiedzi m.in. na te i pokrewne pytania miejmy nadzieję będzie możliwe w efekcie badań nad problematyką wykorzystania koncepcji marketingu terytorialnego przez samorządy do zarządzania własnym rozwojem, które autorka zamierza podjąć.

Zastosowanie zasad marketingu w zarządzaniu gminą, powiatem, miastem, wsią czy województwem może pozwolić na celowe i właściwie, ukierunkowane wykorzystywanie posiadanego przez daną jednostkę terytorialną potencjału i prowadzić do wyższej efektywności podejmowanych na rzecz jej rozwoju działań, a w konsekwencji - osiągnięcia przez daną jednostkę przewagi konkurencyjnej.

Na koniec warto również zwrócić uwagę na fakt, że zastosowanie koncepcji marketingu terytorialnego w zarządzaniu jednostkami terytorialnymi jest $\mathrm{z}$ jednej strony formą i przejawem przedsiębiorczych działań samorządów terytorialnych, ale z drugiej strony może być również traktowane jako swego rodzaju narzędzie wspomagania rozwoju przedsiębiorczości i kreowania postaw oraz zachowań przedsiębiorczych na terenie danej jednostki terytorialnej.

\section{Literatura}

1. Badanie ruchu turystycznego w Małopolsce w roku 2006. Raport końcowy, 2006, Małopolska Organizacja Turystyczna, Kraków 2006, http://www.mot.krakow.pl/index,a,b,c,16.html (odczyt z dnia 02.05.2007).

2. Barczyk S., 2010, Przedsiębiorczy samorząd lokalny i jego instytucje, AE w Katowicach, Katowice.

3. Bieńkowska B., 2004, Lokalne uwarunkowania rozwoju przedsiębiorczości [w:] Przedsiębiorczość stymulatorem rozwoju gospodarczego, J. Brdulak i M. Kulikowski (red.), Instytut Wiedzy, Warszawa.

4. Florek M., 2006, Podstawy marketingu terytorialnego, Wyd. AE w Poznaniu, Poznań.

5. Gołembski G. (red.), 1999, Regionalne aspekty rozwoju turystyki, PWN, Warszawa-Poznań.

6. Gregor B., 2006, Ewolucja oraz wspótczesne koncepcje marketingu [w:] Marketing terytorialny, T. Markowski (red.), tom CXVI, PAN KPZK, Warszawa.

7. Kotler Ph., 1994, Marketing. Analiza, planowanie, wdrażanie i kontrola, Gebethner\&Ska, Warszawa. 
8. Kotler Ph., Haider D.H., Rein I., 1993, Marketing Places. Attracting Investment, Industry and Tourism to Cities, States, and Nations, The Free Press, New York.

9. Kotler Ph., Lee N., 2008, Marketing w sektorze publicznym. Mapa wyższej efektywności, Wyd. Akademickie i Profesjonalne, Warszawa.

10. Majewska J., Wyzwalanie ducha przedsiębiorczości w środowisku społecznym gmin dla rozwoju lokalnego [w:] Rola przedsiębiorczości w podnoszeniu konkurencyjności społeczeństwa i gospodarki, Z. Zioło, T. Rachwał (red.), „Przedsiębiorczość - Edukacja”, nr 2, Nowa Era, Zakład Przedsiębiorczości i Gospodarki Przestrzennej Instytutu Geografii Akademii Pedagogicznej, Warszawa-Kraków.

11. Markowski T., 2006, Marketing miasta [w:] Marketing terytorialny, T. Markowski (red.), tom CXVI, PAN KPZK, Warszawa.

12. Szromnik A., 1997, Marketing terytorialny - geneza, rynki docelowe i podmioty oddziaływania [w:] Marketing terytorialny: strategiczne wyzwania dla miast i regionów, T. Domański (red.), Centrum Badań i Studiów Francuskich Uniwersytetu Łódzkiego, Łódź.

13. Szromnik A., 2006, Marketing terytorialny - koncepcja ogólna a doświadczenia praktyczne [w:] Marketing terytorialny, T. Markowski (red.), tom CXVI, PAN KPZK, Warszawa.

14. Szromnik A., 2007, Marketing terytorialny. Miasto i region na rynku, Wolters Kluwer, Kraków.

15. Zdon-Korzeniowska M., 2009, Jak ksztattować regionalne produkty turystyczne? Teoria i praktyka, Wyd. UJ, Kraków.

\section{Territorial Marketing as a Form of Entrepreneurship of Local Go- vernments in Poland}

Nowadays, functioning of local governments is mostly affected by two phenomena: globalization and locality. Globalizations processes, and among them, tendency to increase the freedom and speed of movement of capital, people, goods and services; give businesses and citizens particular opportunities. These opportunities among others are related with the freedom to choose their place of business, residence, place of work or a place of rest. The above create a specific outlook for the places of reception of investments, businesses or individuals, and so for territorial units managed by local governments. In order to meet the global market requirements, local governments must demonstrate flexibility, innovation and market-based approach, adapting to the needs of interested groups of customers: businesses, tourists, residents, investors.

Counterweight to what entails the processes of globalization is observable tendency to expose what is local by communities to emphasize their own identity and affiliation to the region. Local governments in Poland since the late 90's have gained greater powers and greater freedom of action, which enabled them to implement their role as "managers" of territorial units, which manage, and thus have influence on the directions of development of their "small homelands". To take advantage of emerging, therefore, opportunities, local authorities - as mentioned above - have to demonstrate entrepreneurial and innovative approach. The use of the concept of territorial marketing can be regarded without a doubt as an entrepreneurship attitude of local governments in the conditions of globalization. Market-based approach founded on the marketing concept allows one to increase the efficiency of activities related to resource management of individual territorial units, thus being a useful tool to enhance their competitiveness. This paper contains reflections on application of the concepts of territorial marketing by public authorities to manage their own development. 